\title{
Flow Experiences in Physical Education Classes: The Role of Perceived Motivational Climate and Situational Motivation
}

\author{
Elif Nilay ADA ${ }^{1} \bowtie$ \\ Zisan Kazak ÇETINKALP ${ }^{2}$ \\ M.Ersin ALTIPARMAK ${ }^{3}$ \\ F.Hülya AŞÇI ${ }^{*}$
}

'Mersin University, Physical Education and Sport Department, Çiftlikköy Campus, Yenişehir/Mersin, Turkey 'Email:elifinilavada@gmail.com Tel:+90324.3610001

${ }_{2, s}^{2}$ Ege University, Faculty of Sport Sciences, Bornova/İzmir, Turkey

Email:f:zisan.kazak@gmail.com Tel: +902323425714

Email:ersin.altiparmak@ege.edu.trTel:+902323425714

${ }^{\top}$ Marmara University, Faculty of Sport Sciences, Anadoluhisarı Campus, Beykoz/İstanbul, Turkey

"Email:fhulya@marmara.edu.trTel:+902163085662

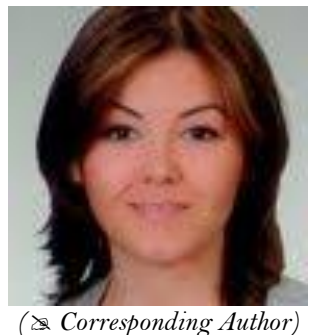

\begin{abstract}
The purpose of this study was to determine the role of perceived motivational climate and situational motivation levels on dispositional flow in physical education classes. 242 boys $\left(\mathrm{M}_{\mathrm{age}}=13.38 ; \mathrm{SD}=0.95\right)$ and 251 girls $\left(\mathrm{M}_{\mathrm{age}}=13.27 ; \mathrm{SD}=0.88\right)$ a total of 493 secondary school students $\left(\mathrm{M}_{\text {age }}=13.32 ; \mathrm{SD}=0.91\right)$ voluntarily participated in this study. Physical Education Situational Motivational Scale, Learning and Performance Orientation in Physical Education Classes Questionnaire and Physical Education Dispositional Flow Scale-2 were administered to all participants. Hierarchical regression analysis indicated that identified regulation, intrinsic motivation, pupil learning climate and teacher-initiated learning explained a significant amount of variance in dispositional flow in physical education $(\mathrm{p}<0.05)$. The pupil learning climate, identified regulation and leisure time sport participation were the strongest predictors, respectively. These findings suggested that promoting mastery-oriented climate, self-determined situational motivation, and participation in sport will foster dispositional flow in the physical education setting.
\end{abstract}

Keywords: Dispositional flow, Situational motivation, Motivational climate, Physical education.

Citation | Elif Nilay ADA; Zisan Kazak ÇETINKALP; M.Ersin ALTIPARMAK; F.Hülya ASCI (2018). Flow Experiences in Physical Education Classes: The Role of Perceived Motivationa Climate and Situational Motivation. Asian Journal of Education and Training, 4(2): 114-120

History:

Received: 13 February 2018

Revised: 2 March 2018

Accepted: 5 March 2018

Published: 7 March 2018

Licensed: This work is licensed under a Creative Commons

Attribution 3.0 License (cc)

Publisher:Asian Online Journal Publishing Group
Contribution/Acknowledgement: All authors contributed to the conception and design of the study.

Funding: This study received no specific financial support.

Competing Interests: The authors declare that they have no conflict of interests.

Transparency: The authors confirm that the manuscript is an honest, accurate, and transparent account of the study was reported; that no vital features of the study have been omitted; and that any discrepancies from the study as planned have been explained.

Ethical: This study follows all ethical practices during writing.

\section{Contents}

1. Introduction

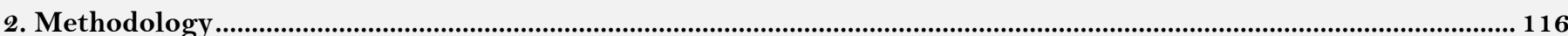

3. Measures ..titis 116

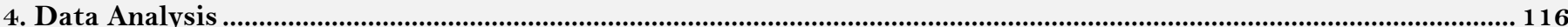

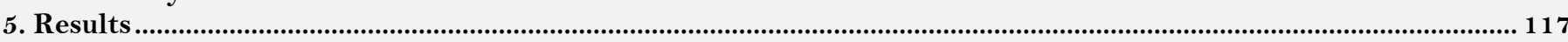

6. Discussion

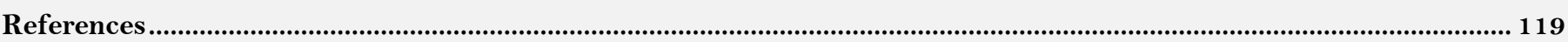




\section{Introduction}

School physical education (PE) has been recognized as one of the most important contexts for obtaining lifelong physical activity habits in youth (Koka and Hagger, 2010). It has been argued that sport, physical activity, and PE have some potential benefits for young people, such as developing physical skills, building character, fostering life skills, encouraging sportsmanship, enhancing teamwork skills, and preparing young people for adult life (Pate, 1983; Goldstein and Iso-Ahola, 2006; Telema et al., 2006; Massarella and Winterstein, 2009; Bernstein et al., 2011; Leech and Marston, 2016).

It is accepted that school physical education is likely to play a critical role in encouraging pupils' participation in the regular physical activity, (Biddle and Chatzisarantis, 1999; Bakirtzoglou and Ioannou, 2011). Pupils who feel motivated toward PE are more likely to gain exercise habits for lifelong (Adams II and Brynteson, 1992). As stated by Pharez (2016) positive experiences in physical education classes can be an essential step toward a more active and healthy lifestyle for all pupils and also a key factor to further participation in other sports activities. Another important key factor is the physical education teacher. Accordingly, creating a positive experience should be the most important duty for PE teachers (Cherubini, 2009; Pharez, 2016; Rukavina and Doolittle, 2016). Moreover, positive climates help to emerge the adaptive outcomes, such as enjoyment and happiness (Ntoumanis, 2001). In positive psychology, there is also a fundamental construct called as flow. Theoretically, this concept accepts the importance of positive experiences. The flow concept was initially introduced by Csikszentmihalyi (1975) and applied in the sport and physical activity contexts by Jackson (1996) and Jackson and Marsh (1996). Optimal experience or flow typically occurs when a person perceives a balance between the challenges associated with a situation and his or her capabilities to accomplish or meet these demands (Csikszentmihalyi, 1990).

It is also very important to know which factors effect flow experience. Swann et al. (2012) have summarized the factors to be the facilitator and inhibitor related to flow in their systematic review study. Some facilitating factors are optimal motivation, optimal arousal, positive thoughts and emotions, and positive feedback whilst the preventing factors have been identified as lacking motivation, lacking confidence, negative feedback, negative thoughts and emotions and poor performance. The factors that inhibit and facilitate the flow are still unclear (Kawabata and Mallett, 2016). This situation is also still unclear in physical education settings.

In addition to these factors, the perceived motivational climate is known as one of the contextual elements that facilitate or inhibit the flow (Kowal and Fortier, 2000; Moreno-Murcia et al., 2008a). The motivational climate has been proposed to have two dimensions called as learning-involving climate (task-involving) and performanceinvolving climate (ego-involving) (Nicholls, 1989; Ames, 1992; Duda, 2001; Xiang et al., 2004; Jaakkola et al., 2016). While learning-involving climate focuses on task mastery, learning, effort exertion and self-improvement (Ames, 1992; Newton et al., 2000) performance-involving climate emphasizes performance outcomes and social comparison between the pupils. However, a performance involving climate leads to increased external motivation and anxiety as well as decreased interest and enjoyment (Duda and Whitehead, 1998). Research which carried out in the field of physical education has shown that task-involving and ego-involving climate are positively related to flow (Papaioannou and Kouli, 1999; Kowal and Fortier, 2000; Cervello et al., 2007; Sicilia et al., 2008; Moreno-Murcia et al., 2008a). Thus, it seems necessary to create a motivational climate that promotes intrinsic motivation, which, in turn, may foster flow. Papaioannou and Kouli (1999) found that pupils' task orientation and perceptions of a taskinvolving motivational climate predicted higher levels of concentration, a more autotelic experience and an absence of self-consciousness. More recent research in physical education settings (Bakirtzoglou and Ioannou, 2011) revealed that both task-involving and ego-involving motivational climates were significantly and positively related to pupils' dispositional flow. Another research has shown that motivation, motivational climate and flow state (flow experience) are interrelated (Kowal and Fortier, 1999; Papaioannou and Kouli, 1999; Moreno-Murcia et al., 2008a; González-Cutre et al., 2009). More specifically, previous studies have shown positive associations between flow state and intrinsic motivation (Deci and Ryan, 1985; Kowal and Fortier, 1999; Camacho et al., 2008).

Conversely, there is a criticism about the relationship between flow and self-determined motivation. Kawabata and Mallett (2016) have stated that full concentration is sufficient for experiencing flow, and people are likely enjoy any activity as long as they entirely concentrate on the activity, regardless of whether they are motivated intrinsically or extrinsically. On the other hand, people need to experience the activity as autonomous to foster intrinsic or self-determined motivation for doing the activity. However, autonomy is not represented as an element in flow theory. Therefore, it is said that motivation type might change, regardless of whether motivation type is needed for experiencing flow. So, the current study also tries to find out the role of situational motivation as well as the perceived motivational climate on flow experiences in the PE context. That is why the relationship between perceived motivational climate, motivation and flow can be further importance, because intrinsic motivation depends on motivational climate that promotes positive outcomes (e.g., Scott et al. (2003)). Intrinsic motivation also can help to find out the flow concept (Deci and Ryan, 1985; Camacho et al., 2008).

Due to all the mentioned reasons, the facilitation of pupils' flow experiences in physical education seems very important, because it can help to enhance a pupil's enjoyment at physical education, as well as motivate participation in physical activity voluntarily during adolescence and later on in life. In the light of these reasons, flow concept can be helpful to teachers, pupils, and the other related persons. Moreover, flow experiences in physical education lessons as an optimal psychological state may be the first factor that affects situations in PE such as pupils' participation and perceived motivational climate. Nevertheless, it is not clear whether motivation level and perceptions of motivational climate influence optimal experience (flow) in secondary school pupils. To extend previous research, the present study aimed to analyze the role of perceived motivational climate and situational motivation on dispositional flow in physical education classes. Therefore, we hypothesized that motivational climate and situational motivation could be the predictor for dispositional flow in physical education settings.

As far as our knowledge, no previous studies on the issues mentioned in this study were examined in Turkey. When the literature is examined, any study had carried out with the same measurement tools and sample group. Additionally, there was no study in the literature about the interaction effect with regard to similar variables. For this reason, the findings obtained from this study can be interesting in comparison to other studies' findings in the literature. However, the previous studies (Kowal and Fortier, 1999; Papaioannou and Kouli, 1999; Moreno-Murcia 
et al., 2008b; González-Cutre et al., 2009) have used the older students, nonstudents or athletes, which is unlike the present study. In this context, the secondary school pupils in Turkey have been seen worthy of investigation, regarding participation motivation, perceived motivational climate and dispositional flow.

\section{Methodology \\ 2.1. Participants}

The participants were recruited from secondary schools in three regions of Izmir city of Turkey. The schools were selected randomly. Two hundred forty two boys $\left(\mathrm{M}_{\text {age }}=13.38 ; \mathrm{SD}=0.95\right)$ and 251 girls $\left(\mathrm{M}_{\text {age }}=13.27 ; \mathrm{SD}=0.88\right)$ totally $493\left(\mathrm{M}_{\mathrm{age}}=13.32 ; \mathrm{SD}=0.91\right)$ secondary school students voluntarily participated in this study. The students were also recruited randomly in each grade level. It was determined that 192 boys and 136 girls participated in sports activities in their leisure time, though 50 boys and 115 girls did not participate in sports activities in their leisure time.

\section{Measures}

\subsection{The Situational Motivation Scale for Physical Education}

The Situational Motivation Scale (SIMS; Guay et al. (2000)) was used to assess individuals' situational (or state) motivation. It has four subscales and four-item subscales that measure intrinsic motivation (IM), identified regulation (IR), external regulation (ER) and amotivation (A). Responding to stem, "Why are you currently engaged in physical education?" participants rate their reasons for participating in physical education class. A 7point Likert type scale ( $1=$ strongly disagree, $7=$ strongly agree) was used to rate the importance of each of the 16 items. The validity and reliability study for physical education lesson were carried out by Daşdan et al. (2012a). The confirmatory factor analysis provided good support for construct validity $\left(\chi^{2} / \mathrm{df}=2.62\right.$, RMSEA=0.06, NFI $=0.94$, $\mathrm{NNFI}=0.96, \mathrm{CFI}=0.97, \mathrm{GFI}=0.93$ and $\mathrm{AGFI}=0.89)$. The internal consistencies of subscales were 0.71 for intrinsic motivation, 0.72 for identified regulation, 0.79 for external regulation and 0.78 for amotivation (Daşdan et al., 2012a).

\subsection{Learning and Performance Orientations in PE Classes Questionnaire (LAPOPECQ)}

The original 26-item LAPOPECQ (Papaioannou, 1994) was administered to measure pupils' perception of achievement orientations in PE classes. The measurement tool had a hierarchical model with five first-order factors and two second-order factors (for review, see Papaioannou (1994)). The scale consists of five subscales: the pupil learning orientation ( 7 items), the teacher initiated learning orientation ( 5 items), the pupil competitive orientation ( 5 items), the pupils' worry about mistakes ( 5 items), and the outcome orientation without effort (4 items). Each item which is following the stem "During today's PE lesson..." was placed on a 5-point Likert-type scale anchored by 1 (strongly disagree) and 5 (strongly agree). The validity and reliability of the scale for the physical education lesson was conducted by Daşdan et al. (2012b). Researchers reported that the results of CFA confirmed the five factors structure. $\left(\chi^{2} / \mathrm{df}=2.35, \mathrm{RMSEA}=0.05, \mathrm{NNFI}=0.98, \mathrm{NFI}=0.92, \mathrm{CFI}=0.98\right.$ and $\left.\mathrm{AGFI}=0.86\right)$. In their study, it has reported that internal consistency values were for subscales 0.88 for pupils' learning, 0.68 for teacher-initiated learning, 0.67 for pupil competitive orientation, 0.72 for pupil worry and 0.50 for outcome orientation without effort.

\subsection{Dispositional Flow State-2 for Physical Education}

Dispositional Flow State-2 which consists of 36 items is used to measure the dispositional optimal experience level in a particular activity. Participants responded to the items on a 5-point Likert type scale ranging from 1 (never) to 5 (always). The DFS-2 has nine subscales (i.e., challenge-skills balance, action-awareness merging, clear goals, unambiguous feedback, concentration on the task at hand, sense of control, loss of self-consciousness, the transformation of time, and autotelic experience) (Jackson and Eklund, 2002). The Dispositional Flow Scale-2 for physical education lesson (DFS-2 for PE) which adapted to Turkish by Daşdan et al. (2012c) was used in this study. In this study, the results of confirmatory factor analysis revealed good fit index values $\left(\chi^{2} / \mathrm{df}=863.11 / 558=1.55\right.$, RMSEA $=0.043, \mathrm{NNFI}=0.96, \mathrm{CFI}=0.97)$. Also, it has reported that the internal consistency values were ranged from 0.46 (challenge-skill balance) to 0.79 (loss of self-consciousness) (Daşdan et al., 2012c). The total scale score was used in this study.

\subsection{Demographic Information}

Participants were asked to provide demographic information for research purpose only (student's age, sex, grade, school name, leisure time sport activity information-where, when, how long and how often). Personal information form did not contain any identity details about students in order that they can give friendly and correct answers.

\section{Data Analysis}

Hierarchical multiple regression analysis (enter method) was used to determine the role of sex, leisure time sport participation, perceived motivational climate and situational motivation on dispositional flow. The model included three steps: (a) sex and leisure time sport participation; (b) subscales of situational motivation and (c) perceived motivational climate subscales. Hierarchical Multiple Regressions assume that there is little or no multicollinearity in the data. Multi-collinearity occurs when the independent variables are not independent from each other (source/reference). Therefore, multi-collinearity was checked in terms of these keys such as adequate sample size, multiple linear correlations (Tolerance and VIF), singularity, the extreme values and normal distribution (Seçer, 2015) criteria.

If the tolerance value is less than 10 and the value of the variance inflation factor is over 10; it means that there is a high relationship between independent variables (Dormann et al., 2013). The results of the analysis showed that 
the tolerance values of all independent variables were between 0.43 and 0.93 , and also variance inflation factor values were between 1.08 and 2.33. Namely, these findings have indicated that there is no statistically significant relationship between the prediction values.

\subsection{Data Collection}

All the required institutional and school approvals were obtained before the start of the study. All potential participants were informed about of the current study, and necessary explanations for the filling of the scales were given by the first researcher. Personal information form and three scales were used in this study. The questionnaires took approximately 25 minutes to complete.

\section{Results}

\subsection{Descriptive Results}

Means and standard deviations of the study variables with regard to sex and leisure time sport participation are presented in Table 1.

Table-1. Means of All Scales With Regard to Sex and Leisure Time Sport Participation

\begin{tabular}{|c|c|c|c|c|c|}
\hline & & Sex & Sport participation & M & $S D$ \\
\hline \multirow{16}{*}{ 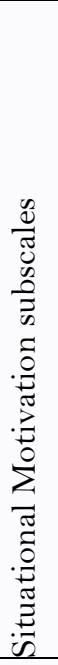 } & \multirow{4}{*}{ Intrinsic motivation } & \multirow[t]{2}{*}{ Boy } & Yes & 6.03 & 0.87 \\
\hline & & & No & 5.40 & 1.03 \\
\hline & & \multirow[t]{2}{*}{ Girl } & Yes & 5.74 & 1.08 \\
\hline & & & No & 5.64 & 1.03 \\
\hline & \multirow{4}{*}{ Identified regulation } & \multirow[t]{2}{*}{ Boy } & Yes & 5.85 & 1.09 \\
\hline & & & No & 5.20 & 1.20 \\
\hline & & \multirow[t]{2}{*}{ Girl } & Yes & 5.49 & 1.21 \\
\hline & & & No & 5.16 & 1.24 \\
\hline & \multirow{4}{*}{ External regulation } & \multirow[t]{2}{*}{ Boy } & Yes & 3.11 & 1.51 \\
\hline & & & No & 3.55 & 1.58 \\
\hline & & \multirow[t]{2}{*}{ Girl } & Yes & 2.83 & 1.42 \\
\hline & & & No & 3.65 & 1.64 \\
\hline & \multirow{4}{*}{ Amotivation } & \multirow[t]{2}{*}{ Boy } & Yes & 2.52 & 1.50 \\
\hline & & & No & 2.81 & 1.41 \\
\hline & & \multirow[t]{2}{*}{ Girl } & Yes & 1.93 & 1.41 \\
\hline & & & No & 2.58 & 1.49 \\
\hline \multirow{20}{*}{ 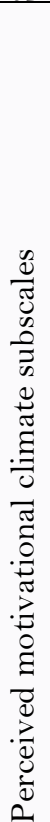 } & \multirow{4}{*}{ Pupils' learning } & \multirow[t]{2}{*}{ Boy } & Yes & 3.96 & 0.92 \\
\hline & & & No & 3.64 & 0.88 \\
\hline & & \multirow[t]{2}{*}{ Girl } & Yes & 4.22 & 0.77 \\
\hline & & & No & 3.98 & 0.84 \\
\hline & \multirow{4}{*}{ Outcome orientation without effort } & \multirow[t]{2}{*}{ Boy } & Yes & 3.20 & 0.96 \\
\hline & & & No & 3.03 & 0.86 \\
\hline & & \multirow[t]{2}{*}{ Girl } & Yes & 3.15 & 0.83 \\
\hline & & & No & 3.14 & 0.91 \\
\hline & \multirow{4}{*}{ Pupil worry } & \multirow[t]{2}{*}{ Boy } & Yes & 3.24 & 0.92 \\
\hline & & & No & 2.93 & 0.84 \\
\hline & & \multirow[t]{2}{*}{ Girl } & Yes & 3.29 & 0.90 \\
\hline & & & No & 3.44 & 1.00 \\
\hline & \multirow{4}{*}{ Pupil competitive orientation } & \multirow[t]{2}{*}{ Boy } & Yes & 3.45 & 0.89 \\
\hline & & & No & 3.22 & 0.87 \\
\hline & & \multirow[t]{2}{*}{ Girl } & Yes & 3.45 & 0.80 \\
\hline & & & No & 3.34 & 0.84 \\
\hline & & Boy & Yes & 3.88 & 0.92 \\
\hline & Teacher initiated learnino & & No & 3.66 & 0.93 \\
\hline & I eacner inimatea learning & Girl & Yes & 4.08 & 0.84 \\
\hline & & & No & 3.83 & 0.90 \\
\hline & & Boy & Yes & 3.95 & 0.67 \\
\hline & Dishositional Flore & & No & 3.48 & 0.66 \\
\hline & Despostilonat r low & Girl & Yes & 3.94 & 0.54 \\
\hline & & & No & 3.62 & 0.68 \\
\hline
\end{tabular}

\subsection{Main Analyses}

The results of hierarchical multiple regression analysis to determine the role of motivational climate, situational motivation, on dispositional flow is presented in Table 2.

Sex and leisure time sport participation had been included as control variables in the analyses. Hierarchical multiple regression analysis results indicated that sex did not predict dispositional flow. On the other hand, leisure time sport participation significantly and negatively predicted dispositional flow. As shown in Table 2, sex was not correlated with the dispositional flow $(\beta=0.028, p>0.05)$, while leisure time sport participation was negatively correlated with the dispositional flow $(\beta=-0.271, \mathrm{p}<0.05)$. Leisure time sport participation explained $7 \%$ of the variance of dispositional flow in the first stage. As shown in Table 2 , intrinsic motivation and identified regulation were positively correlated with dispositional flow ( $\beta=0.145, \mathrm{p}<0.05 ; \beta=0.254, \mathrm{p}<0.05$, respectively), while leisure time sport participation and amotivation were negatively correlated with dispositional flow $(\beta=-0.186, p<0.05 ; \beta=-$ $0.151, \mathrm{p}<0.05$, respectively). Leisure time sport participation, intrinsic motivation, identified regulation and amotivation explained $\% 25$ of the variance in the second stage. 
Table-2. The Results of Hierarchical Multiple Regression Analysis to Determine The Role of Motivational Climate, Situational Motivation on Dispositional Flow.

\begin{tabular}{|c|c|c|c|c|c|c|c|c|c|c|c|c|}
\hline & \multicolumn{4}{|c|}{ Model 1} & \multicolumn{4}{|c|}{ Model 2} & \multicolumn{4}{|c|}{ Model 3} \\
\hline & $B$ & $t$ & $\beta$ & $p$ & $B$ & $t$ & $\beta$ & $p$ & $B$ & $t$ & $\beta$ & $p$ \\
\hline$S$ & 0.04 & 0.61 & 0.03 & & 0.06 & 0.99 & 0.04 & 0.33 & -0.04 & -0.74 & -0.03 & 0.46 \\
\hline LTSP & -0.38 & -5.99 & -0.27 & 0.000 & -0.26 & -4.32 & -0.19 & 0.000 & -0.22 & -4.06 & -0.16 & 0.000 \\
\hline$I M$ & & & & & 0.09 & 3.07 & 0.15 & 0.002 & 0.08 & 2.86 & 0.12 & 0.004 \\
\hline$I R$ & & & & & 0.14 & 5.24 & 0.25 & 0.000 & 0.08 & 3.07 & 0.14 & 0.002 \\
\hline$E R$ & & & & & 0.01 & 0.58 & 0.03 & 0.58 & 0.01 & 0.79 & 0.03 & 0.43 \\
\hline$A$ & & & & & -0.07 & -3.24 & -0.15 & 0.001 & -0.03 & -1.79 & -0.08 & 0.07 \\
\hline PLO & & & & & & & & & 0.25 & 6.12 & 0.33 & 0.000 \\
\hline$O O W E$ & & & & & & & & & 0.02 & 0.52 & 0.02 & 0.61 \\
\hline$P W$ & & & & & & & & & -0.00 & -0.02 & -0.00 & 0.98 \\
\hline$P C O$ & & & & & & & & & 0.02 & 0.52 & 0.02 & 0.60 \\
\hline TIL & & & & & & & & & 0.09 & 2.42 & 0.13 & 0.02 \\
\hline$R$ & \multicolumn{4}{|l|}{0.27} & \multicolumn{4}{|l|}{0.48} & \multicolumn{4}{|l|}{0.63} \\
\hline$R 2$ & \multicolumn{4}{|c|}{0.07} & \multicolumn{4}{|c|}{0.32} & \multicolumn{4}{|l|}{0.39} \\
\hline$F$ & \multicolumn{4}{|c|}{$18.461(2 ; 490)$} & \multicolumn{4}{|c|}{$24.688(4 ; 486)$} & \multicolumn{4}{|c|}{$25.931(5 ; 481)$} \\
\hline$p$ & \multicolumn{4}{|c|}{0.00} & \multicolumn{4}{|c|}{0.00} & \multicolumn{4}{|c|}{0.00} \\
\hline
\end{tabular}
$\mathrm{S}=$ Sex, LTSP $=$ Leisure Time Sport Participation, IM = Intrinsic Motivation, IR = Identified Regulation, ER= External regulation, A = Amotivation, PLO
$=$ Pupil Learning Orientation, OOWE = Outcome orientation without effort, PW = Pupil worry, PCO = Pupil Competition Orientation, TIL= Teacher initiated learning

In the last model, intrinsic motivation, identified regulation, pupil learning orientation and teacher initiated learning were positively correlated with dispositional flow $(\beta=0.121, p<0.05 ; \beta=0.137, p<0.05 ; \beta=0.332, p<0.05$; $\beta=0.125, p<0.05$, respectively), while leisure time sport participation was correlated negatively with dispositional flow $(\beta=-0.156, p<0.05)$. Leisure time sport participation, intrinsic motivation, identified regulation, pupil learning orientation and teacher initiated learning explained $7 \%$ of the variance.

Regarding the predictive power of each predictor variable on dispositional flow, the results explained that pupil learning climate, identified regulation and leisure time sport participation emerged as the strongest predictors. Pupil learning climate and identified regulation were positively and the stronger predictors while leisure time sport participation was negatively and the stronger predictor.

\section{Discussion}

This study aimed to examine the role of perceived motivational climate and situational motivation on dispositional flow. Regression analysis demonstrated that the situational motivation and perceived motivational climate were positive predictors of flow. The meaning of this finding is that flow can emerge if a positive atmosphere can be created during the lesson, such as a more self-determined and supportive climate. On the other hand, it is understood that these positive outcomes are facilitators for experiencing flow. Previous studies had also shown that an individual who is intrinsically motivated should be more prepared to experience flow because she will be interested in the task at hand (Deci and Ryan, 1985; Camacho et al., 2008). With regard to the positive relationship between situational motivation and flow, the majority of the empirical evidence supports SDT and collaboratively suggests more self-determined motivational types, such as intrinsic motivation, will have more positive consequences than the others (Jackson-Kersey and Spray, 2013). Intrinsic motivation has become a facilitator for getting other positive outputs (Ryan and Deci, 2000). There are supportive studies (e.g., (Fullagar and Mills, 2008; Stavrou, 2008)) in the literature about self-determined motivation predicts as positively to flow state. Kowal and Fortier (2000) have found that self-determined motivation were positive predictors of dispositional flow. A study conducted by Fullagar and Mills (2008) found that amotivation in physical education negatively predicted the sense of control and autotelic experience. It means that if a pupil has amotivation, it is not expected to enter the flow channel from her \him (Fullagar and Mills, 2008).

As consistent with the hypothesis of the study, it was found that learning climate (mastery involving)facilitate flow situation. This result has supported the literature. As stated previously, teacher-initiated learning refers to mastery involving climate. Research in PE (e.g., (Papaioannou, 1995; Solomon, 1996; Treasure, 1997; Carpenter and Morgan, 1999; Christodoulidis et al., 2001)) has revealed that perceptions of a mastery climate relate to more positive attitude toward Moreno-Murcia et al. (2008b) have also shown that mastery involved climate in physical education provides a positive and significant prediction of dispositional flow. The researchers showed that mastery involving dimensions were stronger predictors than performance involving dimensions. In this sense, the findings obtained from this study seem to be consistent with the literature.It is understood that If the teachers want to promote dispositional flow in their lesson, the teachers should create a mastery involving climate.

As a result, sport related behaviors can facilitate dispositional flow state. Therefore, children should be encouraged to take participate in sport, and its benefits should be told to every related person (children, families, teachers, and administrations). Some important interventions, such as diversity in the learning environment, to prepare a correct lesson plan according to interest and need, to get pupils involved in the decision-making process, and to change the activity difficulty level according to the main purpose of the course, can be helpful in getting more pleasure, establishing positive outputs and experiencing flow as well. In order to reach these all, the class environment might also be reorganized more effectively and efficiently.

The present findings need to be considered in light of several limitations. First, the findings are based entirely on data from secondary school students, and the data was not collected from other grades as well as teachers. Comparative studies would be necessary for this study. Secondly, the design was correlational, and results could not be interpreted causally. In the future, longitudinal research designs or case studies should be used to understand factors that affect the motivation of students in physical education settings. Future studies can replicate this study on different samples and include both students and teachers by using the different approaches. 


\section{References}

Adams II, T.M. and P. Brynteson, 1992. A comparison of attitudes and exercise habits of alumni from colleges with varying degrees of physical education activity programs. Research Quarterly for Exercise and Sport, 63(2): 148-152. View at Google Scholar $\mid$ View at Publisher

Ames, C., 1992. Achievement goals, motivational climate, and motivational processes. In G. C. Roberts (Ed.), Motivation in sports and exercise. Champaign, IL: Human Kinetics. pp: 161-176.

Bakirtzoglou, P. and P. Ioannou, 2011. Goal orientations, motivational climate and dispositional flow in Greek secondary education students participating in physical education lesson: Differences based on gender. Physical Education and Sport, 9(3): 295-306. View at Google Scholar

Bernstein, E., S.R. Phillips and S. Silverman, 2011. Attitudes and perceptions of middle school students toward competitive activities in physical education. Journal of Teaching in Physical Education, 30(1): 69-83. View at Google Scholar | View at Publisher

Biddle, S.H.J. and N. Chatzisarantis, 1999. Motivation for a physically active lifestyle trough physical education. In Y.V. Avweele, F. Baker, S. Biddle, M. Durand \& R. Seiler (Eds.), Psychology for physical educators. Champaign, IL: Human Kinetics. pp: 5-26.

Camacho, A.S., J. Moreno-Murcia and A.J.R. Tejada, 2008. Motivational profiles and flow in physical education lessons. Perceptual and Motor Skills, 106(2): 473-494. View at Google Scholar | View at Publisher

Carpenter, P.J. and K. Morgan, 1999. Motivational climate, personal goal perspectives, and cognitive and affective responses in physical education classes. European Journal of Physical Education, 4(1): 31-41. View at Google Scholar $\mid$ View at Publisher

Cervello, E.M., A. Escarti and J.F. Guzman, 2007. Youth sport dropout from the achievement goal theory. Psicothema, 19(1): 65-71. View at Google Scholar

Cherubini, J., 2009. Positive psychology and quality physical education. Journal of Physical Education, Recreation \& Dance, 80(7): 42-5 1. View at Google Scholar | View at Publisher

Christodoulidis, T., A. Papaioannou and N. Digelidis, 2001. A year-long intervention to change motivational climate and attitudes towards exercise in greek senior high school. European Journal of Sport Science, 1(4): 1-12. View at Google Scholar

Csikszentmihalyi, M., 1975. Beyond boredom and anxiety. San Fransisco, CA: Jossey-Bass.

Csikszentmihalyi, M., 1990. Flow: The psychology of optimal experience. New York: Harper and Row.

Daşdan, A.E.N., F.H. Aşçı, Ç.F.Z. Kazak and M.E. Altıparmak, 2012a. Validity and reliability of situational motivation scale for physical education class environment. Spormetre, 10(1): 7-12.

Daşdan, A.E.N., F.H. Aşçı, Ç.F.Z. Kazak and M.E. Altıparmak, 2012b. Validity and reliability study of "learning and performance orientations in physical education classes questionnaire” for secondary school students. Turkey Clinics Journal of Sport Sciences, $4(2): 64-71$.

Daşdan, A.E.N., F.H. Așçı, C.F.Z. Kazak and M.E. Altıparmak, 2012c. Evaluation of dispositional flow state scale-2 (DFS-2) for physical education lessons. Hacettepe Journal of Sport Sciences, 23(2): 43-49.

Deci, E.L. and R.M. Ryan, 1985. Intrinsic motivation and self-determination in human behavior. New York: Plenum Press.

Dormann, C.F., J. Elith, S. Bacher, C. Buchmann, G. Carl, G. Carree, J.R.G. Marquez, B. Gruber, B. Lofourcade, P. Leitao, T. Münkemüller, C. McClean, P.E. Osborne, B. Reineking, B. Schröder, A.K. Skidmore, D. Zurell and S. Lautenbach, 2013. Collinearity: A review of methods to deal with it and a simulation study evaluating their performance. Ecography, 36(1): 27-46. View at Google Scholar $\mid$ View at Publisher

Duda, J. and J. Whitehead, 1998. Measurement of goal perspectives in the physical domain. In J. Duda (Ed.), Advances in sport and exercise psychology. Morgantown, WV: FIT. pp: 21-48.

Duda, J.L., 2001. Achievement goal research in sport: pushing the boundaries and clarifying some misunderstandings. In G.Roberts (Ed), Advances in motivation in sport and exercise. Champaign, IL: Human Kinetics. pp: 129-179.

Fullagar, C.J. and M.J. Mills, 2008. Motivation and flow: Toward an understanding of the dynamics of the relation in architecture students. Journal of Psychology, 142(5): 533-556. View at Google Scholar $\mid$ View at Publisher

Goldstein, J.D. and S.E. Iso-Ahola, 2006. Promoting sportsmanship in youth sports: Perspectives from sport psychology. Journal of Physical Education, Recreation \&Dance, 77(7): 18-24. View at Google Scholar $\mid$ View at Publisher

González-Cutre, D., A. Sicilia, J.A. Moreno-Murcia and J.M. Fernandez-Balboa, 2009. Dispositional flow in physical education: Relationships with motivational climate, social goals, and perceived competence. Journal of Teaching in Physical Education, 428(4): 422 -440. View at Google Scholar | View at Publisher

Guay, F., R.J. Vallerand and C. Blanchard, 2000. On the assessment of situational intrinsic and extrinsic motivation: The situational motivation scale (SIMS). Motivation and Emotion, 24(3): 175-2 13. View at Google Scholar

Jaakkola, T., N. Ntoumatis and J. Liukkonen, 2016. Motivational climate, goal orientation, perceived sport ability, and enjoyment within finnish junior ice hockey players. Scandinavian Journal of Medicine \& Science in Sports, 26(1): 109-115. View at Google Scholar $\mid$ View at Publisher

Jackson-Kersey, R. and C. Spray, 2013. Amotivation in physical education: Relationships with physical self-concept and teacher ratings of attainment. European Physical Education Review, 19(3): 289-301. View at Google Scholar $\mid$ View at Publisher

Jackson, S. and R.C. Eklund, 2002. Assessing flow in physical activity: The flow state scale-2 and dispositional flow scale-2. Journal of Sport and Exercise Psychology, 24(2): 133-150. View at Google Scholar $\mid$ View at Publisher

Jackson, S.A., 1996. Toward a conceptual understanding of the flow experience in elite athletes. Research Quarterly for Exercise and Sport, 67(1): 76-90. View at Google Scholar | View at Publisher

Jackson, S.A. and H.W. Marsh, 1996. Development and validation of a scale to measure optimal experience: The flow state scale. Journal of Sport and Exercise Psychology, 18(1): 17-35. View at Google Scholar | View at Publisher

Kawabata, M. and C.L. Mallett, 2016. What is flow? Reconsideration of the state of optimal functioning beyond flow theory. In Robert J. Schinke, Kerry R. McGannon and Brett Smith (Eds). 1st Edn., London: Routledge International Handbook of Sport Psychology. pp: 369-377.

Koka, A. and M.H. Hagger, 2010. Perceived teaching behaviors and self-determined motivation in physical education: A test of selfdetermination theory. Research Quarterly for Exercise and Sport, 81(1): 74-86. View at Google Scholar | View at Publisher

Kowal, J. and M.S. Fortier, 1999. Motivational determinants of flow: Contributions from self-determination theory. Journal of Social Psychology, 139(3): 355-368. View at Google Scholar | View at Publisher

Kowal, J. and M.S. Fortier, 2000. Testing relationships from the hierarchical model of intrinsic and extrinsic motivation using flow as a motivational consequence. Research Quarterly for Exercise and Sport, 71(2): 171-181. View at Google Scholar $\mid$ View at Publisher

Leech, T. and R. Marston, 2016. Promoting physical activity beyond physical education by facilitating student-designed games. Journal of Physical Education, Recreation \& Dance, 87(9): 8-13. View at Google Scholar | View at Publisher

Massarella, F.L. and P.J. Winterstein, 2009. Intrinsic motivation and the flow mental state in street runners. Revista Movimento, 15(2): 4568.

Moreno-Murcia, J.A., N. Alonso, C. Martínez, E. Cervello and L.M. Ruíz, 2008b. Motivation, disciplined behaviour, equal treatment and dispositional flow in physical education students. Journal of International Social Research, 1(4): 446-466.

Moreno-Murcia, J.A., E. Cervelló and D. González-Cutre, 2008a. Relationships among goal orientations, motivational climate and flow in adolescent athletes: Differences by gender. Spanish Journal of Psychology, 11(1): 181-191.

Newton, M., J.L. Duda and Z. Yin, 2000. Examination of the psychometric properties of the perceived motivational climate in sport questionnaire-2 in a sample of female athletes. Journal of Sport Sciences, 18(4): 275-290. View at Google Scholar $\mid$ View at Publisher

Nicholls, J.G., 1989. The competitive ethos and democratic education. Cambridge, MA: Harvard University Press.

Ntoumanis, N., 2001. A self-determination approach to the understanding of motivation in physical education. British Journal of Educational Psychology, 7 1(2): 225-242. View at Google Scholar | View at Publisher

Papaioannou, A., 1994. Development of a questionnaire to measure achievement orientations in physical education. Research Quarterly for Exercise and Sport, 65(1): 11-20. View at Google Scholar | View at Publisher

Papaioannou, A., 1995. Differential perceptual and motivational patterns when different goals are adopted. Journal of Sport and Exercise Psychology, 17(1): 18-34. View at Google Scholar | View at Publisher

Papaioannou, A. and O. Kouli, 1999. The effects of task structure, perceived motivational climate, and goal orientation on students' task involvement and anxiety. Journal of Applied Sport Psychology, 11(1): 51-71. View at Google Scholar $\mid$ View at Publisher 
Pate, R.R., 1983. A new definition of youth fitness. Physician and Sports Medicine, 11 (4): 77-83. View at Google Scholar $\mid$ View at Publisher

Pharez, E.S., 2016. Enjoyment fosters engagement: The key to involving middle school students in physical education and physical activity. Journal of Physical Education, Recreation \& Dance, 87(6): 24-28. View at Google Scholar $\mid$ View at Publisher

Rukavina, P.B. and S.A. Doolittle, 2016. Fostering inclusion and positive physical education experiences for overweight and obese students. Journal of Physical Education, Recreation \& Dance, 87(4): 36-45. View at Google Scholar $\mid$ View at Publisher

Ryan, R.M. and E.L. Deci, 2000. Self-determination theory and the facilitation of intrinsic motivation, social development, and well-being. American Psychologist, 55(1): 68-78. View at Google Scholar | View at Publisher

Scott, C., H. Ken and K. Lynn, 2003. Intrinsic motivation in youth sport: Goal orientations and motivational climate. Journal of Physical Education New Zealand, 36(1): 15-26. View at Google Scholar

Seçer, I., 2015. Practice data analysis and report using SPSS and LISREL. 2nd Edn., Ankara, Turkey: Anı Publishing. pp: 272.

Sicilia, A., J.A. Moreno and A.J. Rojas, 2008. Motivational profiles and flow in physical education lessons. Perceptual and Motor Skills, 106(2): 473-494. View at Google Scholar | View at Publisher

Solomon, M.A., 1996. Impact of motivational climate on students' behaviors and perceptions in a physical education setting. Journal of Educational Psychology, 88(4): 731-738. View at Google Scholar $\mid$ View at Publisher

Stavrou, N.A., 2008. Intrinsic motivation, extrinsic motivation and amotivation: Examining self-determination theory from flow theory perspective. In F. M. Olsson (Ed.), New developments in the psychology of motivation. Hauppauge, NY: Nova Science Publishers. pp: $1-24$.

Swann, C., R.J. Keegan, D. Piggott and L. Crust, 2012. A systematic review of theexperience, occurrence, and controllability of flow states in elite sport. Psychology of Sport and Exercise, 13(6): 807-819. View at Google Scholar $\mid$ View at Publisher

Telema, R., X. Yang, M. Hirvensalo and O. Raitakari, 2006. Participation in organized youth sport as a predictor of adult phy sical activity: A 21-year longitudinal study. Pediatric Exercise Science, 18(1): 76-88. View at Google Scholar $\mid$ View at Publisher

Treasure, D.C., 1997. Perceptions of the motivational climate and elementary school children's cognitive and affective response. Journal of Sport \& Exercise Psychology, 19(3): 278-290. View at Google Scholar | View at Publisher

Xiang, P., A. Bruene and R. McBride, 2004. Using achievement goal theory to assess an elementary physical education running program. Journal of School Health, 74(6): 220-225. View at Google Scholar | View at Publisher 